\title{
Lexical Analysis of Religious Texts using Text Mining and Machine Learning Tools
}

\author{
Mayuri Verma \\ Dayalbagh Educational \\ Institute \\ Agra-282005, India
}

\begin{abstract}
This paper presents a text mining approach to compare and to explore the similarities and the differences between various religious texts using POS Tagging and Term Document Matrix. Automated text mining and machine learning tools have been used for lexical analysis of the ten world famous religious texts: the Holy Bible, the Dhammapada, the Tao Te Ching, the Bhagwad Gita, the Guru Granth Sahib, the Agama, the Quran, the Rig Veda, the Sarbachan and the Torah. The extracted nouns categories were used as features to explore some interesting relationships between these religions and ideas that have emerged in different religions from different geographic regions.
\end{abstract}

\section{General Terms}

Text Mining, Algorithms, Machine Learning

\section{Keywords}

Religious Texts, POS Tagging, R, Lexical Analysis

\section{INTRODUCTION}

Religion has been a subject of study from various standpoints. The historian has been interested in religions as social movements and has taken pains to trace the development of various religions. How has religion come to acquire a place and importance in the life of the humans has been one of the concerns. The sociologist is primarily interested in the institutional and ritualistic aspects of religion. The meaning and functions of a religion cannot be understood fully without a reference to its scriptures. Therefore, to understand religion one has to understand the religious text, be it the Bible for the Christians or the Vedas for the Hindus or the Quran for the Muslims. If these sacred books are taken away from their respective religions, the latter will lose its meaning.

The literary and philosophy scholars use critical and qualitative methods for deep understanding of religious texts. These methods involve going through countless pages of plain text. But with advancement in computing power and free availability of text in digitized form, it has become easy to go through huge amounts of plain-language digitized text to find useful information that's been hiding in plain sight.

Automated lexical analysis techniques are being used nowadays for retrieval of useful information from large amounts of unstructured texts. Several studies have taken place in order to study different religions. Daniel McDonald et al. [1] presented a method for automated extraction of topics from nine religious texts to form a Self-Organizing Map to find relationships between these religious texts. With so many religious texts available in the world only nine were taken into consideration leaving out important world religions i.e.
Buddhism, Jainism , Sikhism .Qahl, Salha Hassan Muhammed et al. [2] developed an automatic similarity detection engine using the Bible and the Quran as corpus to explore the performance of various feature extraction and machine learning techniques. Only two religious texts were taken into consideration and it doesn't give deeper insight into difference in ideas and belief of these two religions. Frank Lloyd Sindler et al. [3] has written a thesis on comparative study of Christian, Jewish and Islamic theodicy. No automated technique have been used to analyze the lexical content of religious texts and only three religions have been taken into consideration. Altogether very little efforts have been made in the past for automated analysis of important religious texts.

Text analytics, also referred to as text mining [4], is a statistical and machine learning methodology for deriving high quality information from unstructured raw information for further analysis via application of natural language processing (NLP) [5] and analytical methods. Text analysis involves information retrieval, lexical analysis to study word frequency distributions, pattern recognition ,tagging/annotation, information extraction, data mining techniques, visualization and predictive analytics.

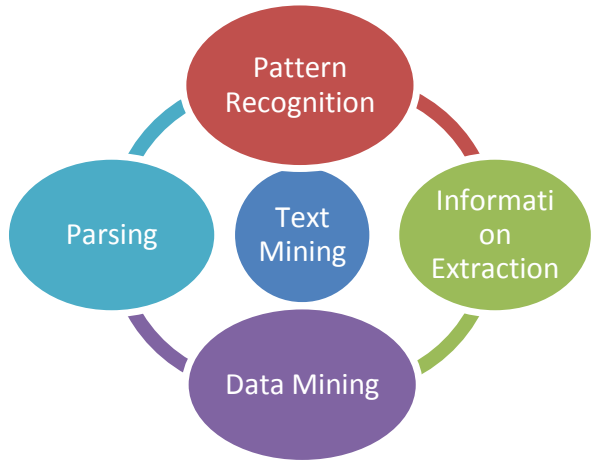

Figure 1: Components of Text Mining

\section{COLLECTION OF RELIGIOUS TEXTS}

The English translations of religious texts were downloaded from the Internet in the pdf format. The books analyzed included the Holy Bible, the Dhammapada, the Tao Te Ching, the Bhagwad Gita, the Guru Granth Sahib, the Agama, the Quran, the Rig Veda, the Sarbachan and the Torah. The selection of books has been done such that the important religions from different parts of the world can be analyzed and studied. 


\subsection{The Holy Bible}

The Holy Bible [6]( The Old Testament and The New Testament) has its origin in the Middle East. The Holy Bible is a group of religious texts of Christianity. It includes laws, stories, prayers, songs, and wise words.We have used the Douay-Rheims version of the Old Testament and the New Testament 1609, 1582 translated from the Latin Vulgate.

\subsection{The Dhammapada}

The Dhammapada [7] originated in India.The Dhammapada is fundamental to religious Buddhism. It is a collection of sayings of the Buddha in verse form and one of the most widely read and best known Buddhist scriptures. The Dhammapada is a collection of 423 verses as uttered by Gautama Buddha himself to his disciples.It is divided into 26 chapters under such headers as Thought, Flowers, Old Age, Self, Happiness, Pleasure, Anger, Thirst, Brahmana and others. We have used the English Translation of the text from Pali by F. Max Muller.

\subsection{The Tao Te Ching}

The Tao Te Ching [8] originated in China.The Tao Te Ching is fundamental to the religious Taoism. The oldest excavated portion dates back to the late 4th century BCE. The book was originally written in classical Chinese using seal script. The English Translation of Tao Te Ching has been used for the analysis and study.

\subsection{The Bhagwad Gita}

The Bhagwad Gita [9] is originated in India. It is the sacred book of the religious Hinduism. The Bhagavad Gita is a 700verse Hindu scripture in Sanskrit that is part of the Hindu epic Mahabharata (chapters 23-40 of the 6th book of Mahabharata), ascribed to the Sage Vyasa. The English Translation of Bhagwad Gita by A.C. Bhaktivedanta Swami Prabhupada has been used for the analysis.

\subsection{The Guru Granth Sahib}

The Guru Granth Sahib [10] originated in Northern India. Guru Granth Sahib is the central religious scripture of Sikhism, regarded by Sikhs as the final, sovereign and eternal living Guru following the lineage of the ten human Gurus of the religion, of whom six contributed the bulk.The English translation of Guru Granth Sahib by Singh Sahib Sant Singh Khalsa has been used for the analysis.

\subsection{The Agama}

The Agama [11] has its origin in India. Agamas are texts of religious Jainism based on the discourses of the tirthankara Some authors date the composition of Jain Agamas starting from the 6th century BCE.The English translation by Hita Ajmera, Hemal Doshi, Nandita Sheth, Samir Sheth, Swati Kamdar,Vishal Parekh, Jayshri Doshi, Ami Damani and Girish Shah has been used for the analysis.

\subsection{The Quran}

The Quran [12] has its origin in the Middle East. The Quran is the sacred text of Islam. Muslims believe that the Quran was verbally revealed by God to Muhammad through the angel Gabriel. The Quran is divided into chapters (surah in Arabic), which are then divided into verses (ayah).The English Translation of the Quran by Talal Itani has been used for the analysis and study.

\subsection{The Rig Veda}

The Rig Veda [13] has its origin in India. The Rigveda is an ancient Indian collection of Vedic Sanskrit hymns.It is a collection of 1,028 hymns and 10,600 verses, organized into ten books. It is the book of the religious Hinduism and is the oldest extant texts in any Indo-European language. The English translation of the text by Ralph T. H. Griffith (2nd edition), Kotagiri (Nilgiri) 1896, has been used for the analysis.

\subsection{The Sarbachan}

The Sarbachan [14] has its origin in India. The Sarbachan is the religious text of the Radhasoami Faith. The teachings of Soami Ji Maharaj, the founder of the Radhasoami Faith, were published in the form of Sarbachan in prose. The English translation of the Sarbachan by S.D. Maheshwari has been used for the analysis.

\subsection{The Torah}

The Torah [15] has its origin in the MiddleEast. It is the central text of the religious Judaism. The English translation of Torah published by the Wellsprings of Torah, a Messianic Congregation has been used for analysis .

\section{PARTS OF SPEECH (POS) TAGGING OF TEXT}

After selecting the books for the lexical analysis, Part-ofspeech tagging (POS tagging) of the words, constituting the religious texts was done using the "openNLP" package in R [16]. The Part-of-speech tagging is the process of marking up a word in a text (corpus) as corresponding to a particular part of speech, based on both its definition and its context. The POS tags used by the "openNLP" package are the Penn English Treebank POS tags.

\section{EXTRACTION OF LEXICAL TOKENS}

POS tagging was followed by extraction of lexical tokens or words from the texts was done using R. Lexical tokens are the words which primarily convey information, which include nouns, verbs, adjectives and adverbs. Words or tokens other than lexical tokens are known as functional tokens.The total breakdown of terms into nouns, verbs, adjectives and adverbs between the ten books is reported in Table 2.The observations made are as follows:

- The Holy Bible had the largest number of tokens followed by the Guru Granth Sahib, the Rig Veda,the Torah, the Quran, the Sarbachan, the Bhagwad Gita, the Agama, the Dhammapada, and followed by the Tao Te Ching with minimum token count as reported in Figure 3.

\section{TOTAL WORDS}

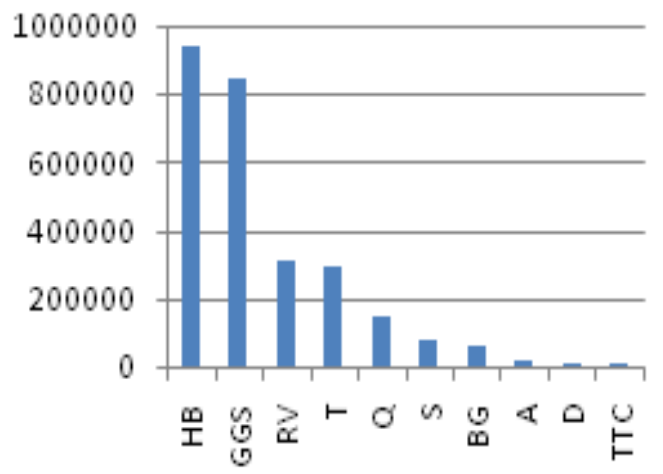

Figure 2: Comparison of Religious Texts based on total number of Words 
- Nouns made up 15 to 40 percent of the terms, verbs made up 7 to 21 percent of the terms, the Adjectives made up 2.5 to 40 percent of the terms and the adverbs made up 1 to 9 percent of the terms.

- As shown in figure 4, the Agama, the Rig Veda ,the Bhagwad Gita and the Sarbachan had a greater number of Nouns than other texts did.

NOUNS (\%)

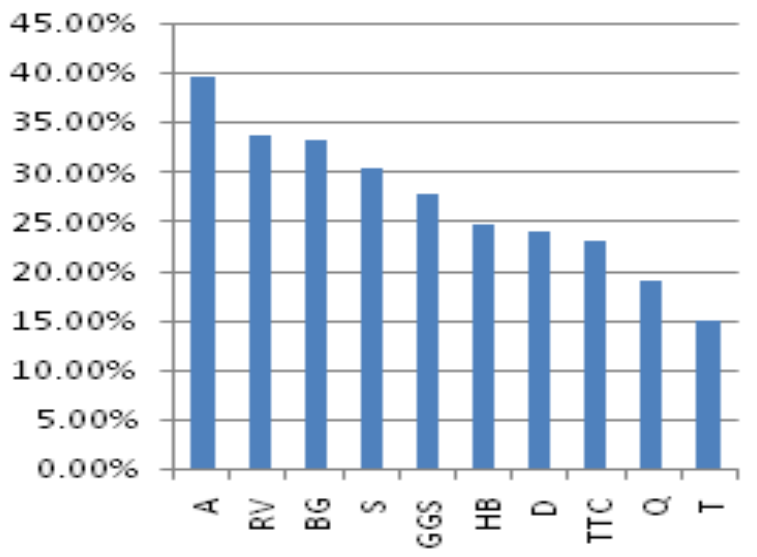

Figure 3: Comparision of Religious Texts based on total Noun categories

- As shown in figure 5, the Tao Te Ching, the Quran, the Dhammapada and the Guru Granth Sahib had a greater number of verbs than other texts did.

\section{$\operatorname{VERBS}(\%)$}

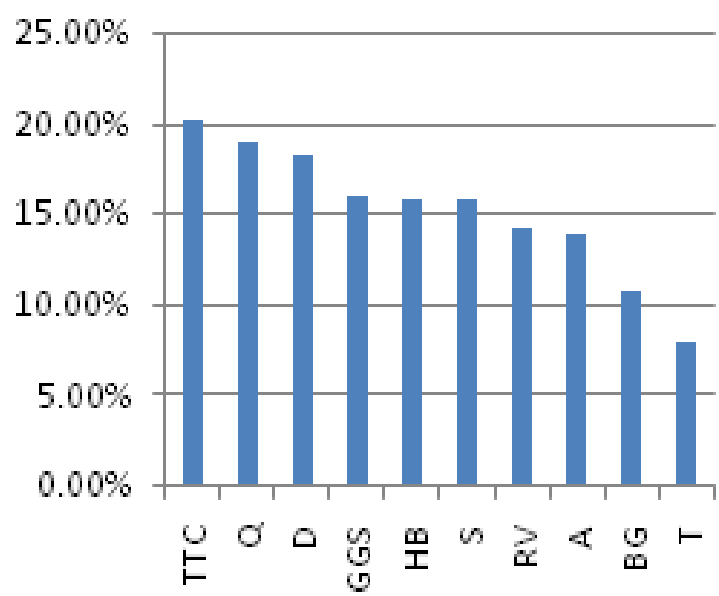

Figure 4: Comparision of Religious Texts based on total Verb categories

- It was observed that the books which has a larger number of nouns subsequently showed an opposite behaviour with a smaller percentage of verbs than the other books.

- $\quad$ The Quran, the Tao Te Ching and the Dhammapada had similar number of nouns and verbs.

- After combining the lexical tokens together, the Bible, the Guru Granth Sahib and the Rig Veda had the largest number of lexical tokens.

\section{CALCULATION OF LEXICAL RICHNESS OF RELIGIOUS TEXTS}

The most popular measures used in the measurement of Lexical Richness are Lexical Density(LD) and Lexical Variation(LV) [17 ].

Lexical Density is defined as the percentage of lexical words in the text, i.e. nouns, verbs, adjectives , adverbs:

$$
L D=\frac{\text { Number of Lexical Tokens }}{\text { Total Number of Tokens }} \times 100
$$

Lexical Variation(LV) is the type/token ratio, i.e. the ratio in percent between the different words in the text and the total number of running words:

$$
L D=\frac{\text { Number of Types }}{\text { Total Number of Tokens }} \times 100
$$

The Lexical Density(LD) and Lexical Variation(LV) of the ten religious texts was calculated as shown in Table 3. The observations made are as follows:

- The Agama had the highest Lexical Density followed by the Rig Veda and the Tao Te Ching. The Torah had the least Lexical Density as shown in Figure 6.

- The Bhagwad Gita had the highest Lexical Variation followed by the Agama and the Tao Te Ching.The Guru Granth Sahib had the least Lexical Variation as shown in Figure 6.

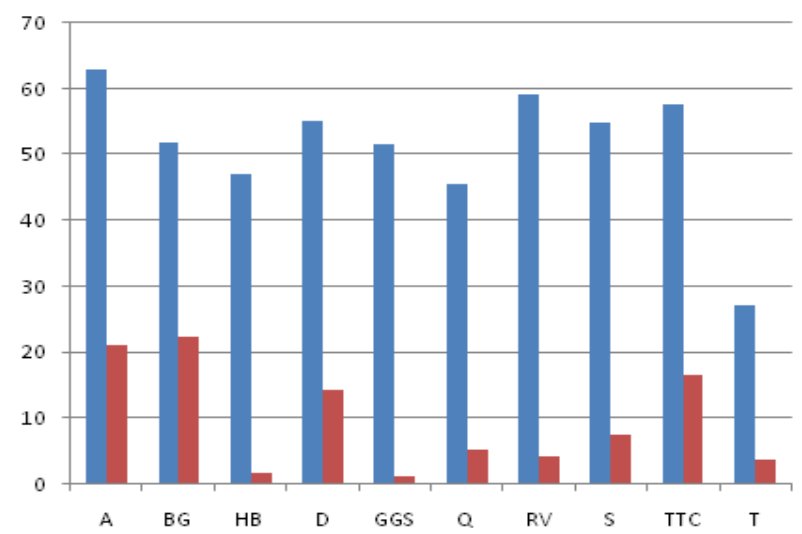

Figure 5: Comparision of Religious Texts based on Lexical Density and Lexical Variation(blue bar=Lexical Density, red bar=Lexical Variation)

\section{CATEGORISATION OF COMMON NOUNS}

In order to find the important noun categories of all the religious texts, term document matrix has been created using the "tm" package in R [ 18]. The term document matrix describes the frequency count of words among all resumes. In the term document matrix , each row represents one religious text and each column represents a word(noun) and each entry represents the frequency count of a particular word in that particular resume. Some pre processing steps have been used to create the term document matrix. All the punctuation marks have been removed have been removed since these are of no significant use, all the Upper case letters have been converted into lower case in order to maintain the similarity and words are stemmed so that any differences in the tenses or the usage 
of the words would not be able to affect the term document matrix.The extracted nouns were categorized into common noun categories with most common examples as shown in Table 4.The observations made are as follows:

- Apart from common internal body parts, only the Torah and the Holy Bible had references to flesh as a unique body part instance.

- The Quran had a greater number of references to emotions like danger, fear, hatred, anger, duties, burdens than other texts did.

- $\quad$ The Bhagwad Gita ,the Quran and the Tao Te Ching had a large number of references to sacrifice.

- Hour, month and year were the common units to measure time periods. Unlike other religious texts, the Tao Te Ching had references to only morning in the date/time category.

- The Holy Bible had references to the Babylon and the Jeremia. And the Torah had references to the Israel and the Egypt in the place category.

- The 'Lotus' emerged as the one and only flower referred to in the religious texts i.e. the Bhagwad Gita ,the Dhammapada, the Guru Granth Sahib, the Rig Veda and the Sarbachan, all having Indian origin.

- The religious texts having Indian origin had greater references to the five important elements of Nature i.e. fire, air/wind, water, earth and the sky which indicates that according to these texts these elements play an important role in human life.

- The Rig Veda had maximum references to God under different namesi.e.Indra,soma,varuna,indu,surya,rudra,brahas pati,visvedeva,saraswati,yama,kali and Vishnu. Similarly, the Bhagwad Gita had multiple references to God as Vishnu, shiva,rudra,yama,indra,varuna,soma,kali,Krishna and arjuna. Both belong to the religious Hinduism and share names of God.

Another striking observation was that these were the names of the five essential elements of Nature in the regional language of India i.e. Hindi. This shows that the followers of Hinduism worshipped the five elements of Nature as God.

- The Holy Bible, the Rig Veda had greatest number of references to the precious stones/metals i.e.gold,silver,pearl,ornament and diamond.

The Tao Te Ching had no references to this category.

- The Rig Veda, the Bhagwad Gita and the Guru Granth Sahib had the maximum number of common animal instances.

- All the religions with Indian origin had references to hymns, songs and prayers as a medium to communicate with God.

- All the religions had a reference to 'boat' as the water vehicle.

- All the religions with the Indian origin had a large number of instances of 'yoga' and 'yogi'. The Rig Veda, the oldest sacred texts, had the maximum instances of these words depicting the origin of yoga in India thousands of years ago.

- Another striking observation made was the large number of occurrences of the word 'one' throughout all religions. This indicates that all the religious texts believe in the existence of one eternal God.
- There is a reference to a festival known as 'Holi' in the Agama, the Guru Granth Sahib, the Rig Veda and the Sarbachan.

- Another interesting observation made was that in there were some instances of the Holy Bible and the Torah in the Quran, all three belonging to the same origin i.e. the Middle East.They weretorah,pharaoh,noah,joseph,aaron,Isaac,Jacob,altar,je sus,Solomon, church,Babylon.

- The Sarbachan had instances belonging to the Bhagwad Gita , the Aama, the Rig Veda, the Quran and the Guru Granth Sahib.They werejain,sri,Krishna,veda,shiva,Vishnu,brahma,kali,musl im,nanak,quran.

- The Guru Granth Sahib had instance belonging to the religious Hinduism i.e. Krishna.

- These results show that the religions belonging to the same geographic region influenced each other and they also relate or compared themselves with the other religions of the same geographic region.

\section{CONCLUSION AND FUTURE WORK}

The results of the Lexical Analysis of Religious Texts clearly show that the religious texts originating from the same Geographic region had maximum number of shared Noun categories. This indicates that geographic regions had an impact on these religious texts. Some religious texts had references to the God of other religions indicating that those religious texts compared themselves with other religions of the same geographic region.

In future even more religious texts can be included in the analysis and Hierarchical Clustering can be performed to explore the similarities and the differences between different religions belonging to different geographic regions. Also various religious texts of the same religion from different era can be compared and analysed to study how a religion evolved and developed with time.

\section{REFERENCES}

[1] Daniel McDonald. "A Text Mining Analysis of Religious Texts". The Journal of Business Inquiry ,2014.

[2] Qahl, Salha Hassan Muhammed, "An Automatic Similarity Detection Engine Between Sacred Texts Using Text Mining and Similarity Measures" (2014). Thesis. Rochester Institute of Technology.

[3] Frank Lloyd Sindler." COMPARATIVE STUDY OF CHRISTIAN, JEWISH, AND ISLAMIC THEODICY"(1982).Thesis. B.S., Clemson University.

[4] Feldman, Ronen, and James Sanger. The text mining handbook: advanced approaches in analyzing unstructured data. Cambridge University Press, 2007.

[5] Manning, Christopher D., and Hinrich Schütze. Foundations of statistical natural language processing. Vol. 999. Cambridge: MIT press, 1999.

[6] The Holy Bible, translated from the Latin Vulgate https://archive.org/details/holybibletransla00chalrich

[7] Free Books To Read Audio Libary http://freebookstoread.com/dhmpd10_1.htm

[8] The Holy Bible, translated from the Latin Vulgate http://www.with.org/tao_te_ching_en.pdf 
[9] Bhagavad-Gita As It Is: http://www.bhagavatgita.ru/ files/Bhagavad-gita_As_It_Is.pdf

[10] English Translation of Siri Guru Granth Sahib http://old.sgpc.net/CDN/English\%20Translation\%20of\% 20Siri\%20Guru\%20Granth\%20Sahib.pdf

[11]AGAMA - An Introduction: http://jainaagam.org/ download_pdf/Aagam_Intro_Booklet\%20v280912.pdf

[12] Quran English Translation http://www.clearquran.com/ downloads/quran-english-translation-clearquran-editionallah.pdf

[13] The Hymns of the Rigveda: http://www.sanskritweb .net/rigveda/griffith.pdf
[14] SAR BACHANRÁDHÁSOÁMÍ (Poetry) https://www.scribd.com/doc/118290685/Sar-BachanRadhasoami-Poetry-Volume-One

[15] Torah Bible of Jewish http://text.123doc.org/document/4213026-torah-bible-ofjewish.htm

[16] Martin Schweinberger.” Part-Of-Speech Tagging with R "(June 24, 2016)

[17] Vocabulary Size and Use: Lexical Richness in L2 ... Oxford

Academic

https://academic.oup.com/applij/article-

abstract/16/3/307/184110/Vocabulary-Size-and-Use-

Lexical-Richness-in-L2

[18] Text Mining Package https://cran.rproject.org/web/packages/tm/tm.pdf

\section{APPENDIX}

Table 1: Tallies for Categories of Lexical Tokens across Religious Books

\begin{tabular}{|l|l|l|l|l|l|l|l|l|l|l|l|}
\hline $\begin{array}{l}\text { Holy } \\
\text { Books }\end{array}$ & $\begin{array}{l}\text { Nouns } \\
\text { (Total) }\end{array}$ & $\begin{array}{l}\text { Nouns } \\
(\boldsymbol{\%})\end{array}$ & $\begin{array}{l}\text { Verbs } \\
\text { (Total) }\end{array}$ & $\begin{array}{l}\text { Verbs } \\
(\boldsymbol{\%})\end{array}$ & $\begin{array}{l}\text { Adjecti } \\
\text { ves } \\
\text { (Total) }\end{array}$ & $\begin{array}{l}\text { Adjecti } \\
\text { ves } \\
(\boldsymbol{\%})\end{array}$ & $\begin{array}{l}\text { Adverb } \\
\mathbf{\text { s }} \\
\text { (Total) }\end{array}$ & $\begin{array}{l}\text { Adverb } \\
\mathbf{s} \\
(\%)\end{array}$ & $\begin{array}{l}\text { Others } \\
\text { (Total) }\end{array}$ & $\begin{array}{l}\text { Others } \\
(\%)\end{array}$ & $\begin{array}{l}\text { Total } \\
\text { Words }\end{array}$ \\
\hline $\begin{array}{l}\text { Agama } \\
\text { A) }\end{array}$ & 7957 & 39.58 & 2783 & 13.84 & 1354 & 6.73 & 572 & 2.84 & 7436 & 37.01 & 20102 \\
\hline $\begin{array}{l}\text { Bhagw } \\
\text { ad Gita } \\
\text { (BG) }\end{array}$ & 19328 & 33.21 & 6237 & 10.71 & 2864 & 4.92 & 1713 & 8.86 & 8514 & 42.30 & 58200 \\
\hline $\begin{array}{l}\text { Bible } \\
\text { (HB) }\end{array}$ & 230682 & 24.63 & 147106 & 15.71 & 32508 & 3.47 & 31757 & 3.39 & 494629 & 52.80 & 936682 \\
\hline $\begin{array}{l}\text { Dhamm } \\
\text { apada } \\
\text { (D) }\end{array}$ & 2898 & 23.85 & 2216 & 18.24 & 951 & 7.83 & 638 & 5.25 & 5447 & 44.83 & 12150 \\
\hline $\begin{array}{l}\text { Guru } \\
\text { Granth } \\
\text { Sahib } \\
\text { (GGS) }\end{array}$ & 233700 & 27.67 & 134347 & 15.91 & 42215 & 4.99 & 25897 & 3.07 & 408457 & 48.36 & 844616 \\
\hline $\begin{array}{l}\text { Quran( } \\
\text { Q) }\end{array}$ & 28196 & 18.87 & 28322 & 18.95 & 5966 & 3.99 & 5736 & 3.84 & 81182 & 54.35 & 149402 \\
\hline $\begin{array}{l}\text { Rig } \\
\text { Veda(R } \\
\text { V) }\end{array}$ & 102783 & 33.54 & 43225 & 14.12 & 24614 & 8.03 & 10415 & 3.39 & 125379 & 40.92 & 306416 \\
\hline $\begin{array}{l}\text { Sarbach } \\
\text { an(S) }\end{array}$ & 23155 & 30.41 & 11929 & 15.67 & 3920 & 5.15 & 2722 & 3.57 & 34409 & 45.20 & 76135 \\
\hline $\begin{array}{l}\text { Tao Te } \\
\text { Ching } \\
\text { (TTC) }\end{array}$ & 2214 & 22.87 & 1943 & 20.07 & 866 & 39.11 & 553 & 5.71 & 4105 & 12.24 & 9681 \\
\hline $\begin{array}{l}\text { Torah } \\
\text { (T) }\end{array}$ & 44540 & 15.02 & 23480 & 7.92 & 7408 & 2.50 & 5093 & 1.72 & 215902 & 72.84 & 296423 \\
\hline
\end{tabular}

Table 2: Tallies for Lexical Density and Lexical Variation Across Religious Books

\begin{tabular}{|l|l|l|l|l|l|}
\hline Holy Books & $\begin{array}{l}\text { Total Number } \\
\text { Of } \\
\text { Lexical } \\
\text { Tokens }\end{array}$ & $\begin{array}{l}\text { Total Types } \\
\text { Of Tokens }\end{array}$ & $\begin{array}{l}\text { Total Number } \\
\text { Of } \\
\text { Tokens }\end{array}$ & $\begin{array}{l}\text { Lexical } \\
\text { Density(\%) } \\
(\text { LD })\end{array}$ & $\begin{array}{l}\text { Lexical } \\
\text { Variation(\%) } \\
(\text { LV) }\end{array}$ \\
\hline Agama(A) & 12666 & 4262 & 20102 & 63.01 & 21.20 \\
\hline $\begin{array}{l}\text { Bhagwad } \\
\text { Gita(BG) }\end{array}$ & 30142 & 12985 & 58200 & 51.79 & 22.31 \\
\hline $\begin{array}{l}\text { Holy } \\
\text { Bible(HB) }\end{array}$ & 442053 & 16167 & 936682 & 47.19 & 1.73 \\
\hline $\begin{array}{l}\text { Dhammapada( } \\
\text { D) }\end{array}$ & 6703 & 1750 & 12150 & 55.17 & 14.40 \\
\hline
\end{tabular}




\begin{tabular}{|l|l|l|l|l|l|}
\hline $\begin{array}{l}\text { Guru Granth } \\
\text { Sahib(GGS) }\end{array}$ & 436159 & 10111 & 844616 & 51.64 & 1.20 \\
\hline Quran(Q) & 68220 & 7924 & 149402 & 45.66 & 5.30 \\
\hline Rig Veda(RV) & 181037 & 12985 & 306416 & 59.08 & 4.24 \\
\hline Sarbachan(S) & 41726 & 5728 & 76135 & 54.80 & 7.52 \\
\hline $\begin{array}{l}\text { Tao Te } \\
\text { Ching(TTC) }\end{array}$ & 5576 & 1608 & 9681 & 57.60 & 16.61 \\
\hline Torah(T) & 80521 & 11300 & 296423 & 27.16 & 3.81 \\
\hline
\end{tabular}

Table 3: Important Noun Categories with instances across all Religious Books

\begin{tabular}{|c|c|c|c|c|c|c|c|c|c|c|}
\hline $\begin{array}{c}\text { Categori } \\
\text { es }\end{array}$ & Agama & $\begin{array}{c}\text { Bhagwa } \\
\text { d Gita }\end{array}$ & $\begin{array}{l}\text { Holy } \\
\text { Bible }\end{array}$ & $\begin{array}{c}\text { Dhamm } \\
\text { apada }\end{array}$ & $\begin{array}{c}\text { Guru } \\
\text { Granth } \\
\text { Sahib }\end{array}$ & Quran & $\begin{array}{c}\text { Rig } \\
\text { Veda }\end{array}$ & $\begin{array}{c}\text { Sarbach } \\
\text { an }\end{array}$ & $\begin{array}{l}\text { Tao Te } \\
\text { Ching }\end{array}$ & Torah \\
\hline $\begin{array}{l}\text { Family } \\
\text { Relations } \\
\text { hips }\end{array}$ & $\begin{array}{l}\text { Mother,s } \\
\text { on,child,f } \\
\text { ather,wif } \\
\text { e }\end{array}$ & $\begin{array}{l}\text { Son,mot } \\
\text { her,fathe } \\
\text { r } \\
\text {,children, } \\
\text { wife }\end{array}$ & $\begin{array}{l}\text { Son,fathe } \\
\text { r,mother, } \\
\text { husband, } \\
\text { children }\end{array}$ & $\begin{array}{l}\text { Mother,f } \\
\text { ather,son } \\
\text {,wife,chil } \\
\text { dren }\end{array}$ & $\begin{array}{l}\text { Husband, } \\
\text { mother,c } \\
\text { hild,fathe } \\
\text { r,wife,da } \\
\text { ughter }\end{array}$ & $\begin{array}{l}\text { Mother,s } \\
\text { on,father, } \\
\text { children, } \\
\text { wive,bret } \\
\text { hren }\end{array}$ & $\begin{array}{l}\text { Mother,s } \\
\text { on,father, } \\
\text { child,hus } \\
\text { band,brot } \\
\text { her,sister }\end{array}$ & $\begin{array}{l}\text { Mother,h } \\
\text { usband,f } \\
\text { ather,son } \\
\text {,brother, } \\
\text { wife,chil } \\
\text { d }\end{array}$ & $\begin{array}{l}\text { Mother,s } \\
\text { on,childr } \\
\text { en }\end{array}$ & $\begin{array}{l}\text { Mother,f } \\
\text { ather,chil } \\
\text { dren,son, } \\
\text { wife,chil } \\
\text { d }\end{array}$ \\
\hline $\begin{array}{l}\text { External } \\
\text { Body } \\
\text { Parts }\end{array}$ & $\begin{array}{l}\text { Head,eye } \\
\text {,feet,hair, } \\
\text { hnd,mout } \\
\text { h,knee }\end{array}$ & $\begin{array}{l}\text { Eye,mou } \\
\text { th,feet,ar } \\
\text { m,palm, } \\
\text { teeth,ear, } \\
\text { hair }\end{array}$ & $\begin{array}{l}\text { Hand,fee } \\
\text { t,eye,hea } \\
\text { d,face,m } \\
\text { outh,tong } \\
\text { ue }\end{array}$ & $\begin{array}{l}\text { Tongue,h } \\
\text { air,arm,h } \\
\text { and,feet, } \\
\text { head,eye, } \\
\text { mouth,ea } \\
\text { r }\end{array}$ & $\begin{array}{l}\text { Feet,tong } \\
\text { ue,forehe } \\
\text { ad,eye,m } \\
\text { outh,pal } \\
\text { m }\end{array}$ & $\begin{array}{l}\text { Hand,eye } \\
\text {,face,feet } \\
\text {,ear,head } \\
\text {,palm,mo } \\
\text { uth, }\end{array}$ & $\begin{array}{l}\text { Arm,ton } \\
\text { gue,eye, } \\
\text { mouth,fo } \\
\text { ot,hair,te } \\
\text { eth,ear }\end{array}$ & $\begin{array}{l}\text { Feet,eye, } \\
\text { head,nec } \\
\text { k,head,er } \\
\text {,arm,tong } \\
\text { ue,mouth }\end{array}$ & $\begin{array}{l}\text { Arm,eye, } \\
\text { ear,mout } \\
\text { h,foot,ha } \\
\text { nd }\end{array}$ & $\begin{array}{l}\text { Teeth,pal } \\
\text { m,head,s } \\
\text { houlder,e } \\
\text { ar,face,e } \\
\text { ye.feet }\end{array}$ \\
\hline $\begin{array}{l}\text { Internal } \\
\text { Body } \\
\text { Parts }\end{array}$ & $\begin{array}{l}\text { Mind,hea } \\
\text { rt,limb,w } \\
\text { omb,bon } \\
\text { e,blood }\end{array}$ & $\begin{array}{l}\text { Flesh,mi } \\
\text { nd,heart, } \\
\text { womb,bl } \\
\text { ood }\end{array}$ & $\begin{array}{l}\text { Heart,mi } \\
\text { nd,womb } \\
\text {,bone,blo } \\
\text { od,breast }\end{array}$ & $\begin{array}{l}\text { Heart,mi } \\
\text { nd,bone, } \\
\text { blood }\end{array}$ & $\begin{array}{l}\text { Mind,hea } \\
\mathrm{rt}, \text { womb, } \\
\text { bone,bre } \\
\text { ast,blood }\end{array}$ & $\begin{array}{l}\text { Heart,wo } \\
\text { mb,bone, } \\
\text { blood,bre } \\
\text { ast }\end{array}$ & $\begin{array}{l}\text { Heart,mi } \\
\text { nd,limb, } \\
\text { womb,bo } \\
\text { ne,blood, } \\
\text { breast }\end{array}$ & $\begin{array}{l}\text { Mind,hea } \\
\text { rt,breast, } \\
\text { womb,bo } \\
\text { ne }\end{array}$ & $\begin{array}{l}\text { Mind,hea } \\
\text { rt,bone }\end{array}$ & $\begin{array}{l}\text { Flesh,blo } \\
\text { od,womb } \\
\text {,breast,b } \\
\text { one,heart }\end{array}$ \\
\hline Emotions & $\begin{array}{l}\text { Anger,pa } \\
\text { in,pleasu } \\
\text { re,love,h } \\
\text { atred,free } \\
\text { dom,joy, } \\
\text { sorrow }\end{array}$ & $\begin{array}{l}\text { Pleasure, } \\
\text { pain,fear, } \\
\text { love,ang } \\
\text { er,happin } \\
\text { ess } \\
\text {,sorrow,f } \\
\text { reedom,h } \\
\text { ope,hono } \\
\text { r,danger, } \\
\text { ego,pride } \\
\text {,hate }\end{array}$ & $\begin{array}{l}\text { Pain,fear, } \\
\text { joy,hope, } \\
\text { love,hon } \\
\text { or,hate,d } \\
\text { anger,an } \\
\text { ger,terror } \\
\text {,pride,wr } \\
\text { ath }\end{array}$ & $\begin{array}{l}\text { Pain,plea } \\
\text { sure,hap } \\
\text { piness,fe } \\
\text { ar,love,h } \\
\text { atred,ang } \\
\text { er,sorrow } \\
\text {,freedom, } \\
\text { joy,dang } \\
\text { er,honor }\end{array}$ & $\begin{array}{l}\text { Love,pai } \\
\mathrm{n} \text {,egotis } \\
\mathrm{m} \text {,fear,ho } \\
\text { pe,anger, } \\
\text { danger }\end{array}$ & $\begin{array}{l}\text { Pleasure, } \\
\text { hate,fear, } \\
\text { wrath,da } \\
\text { nger }\end{array}$ & $\begin{array}{l}\text { Joy,delig } \\
\text { ht,love,pl } \\
\text { easure,fr } \\
\text { eedom,a } \\
\text { nger,dan } \\
\text { ger,fear,h } \\
\text { ope,sorro } \\
\text { w,terror, } \\
\text { pain }\end{array}$ & $\begin{array}{l}\text { Plesaure, } \\
\text { pain,fear, } \\
\text { anger,ho } \\
\text { nor,sorro } \\
\text { w,laugh, } \\
\text { delight,di } \\
\text { stress }\end{array}$ & $\begin{array}{l}\text { Honor,fe } \\
\text { ar,distres } \\
\text { s,sorrow, } \\
\text { danger,lo } \\
\text { ve }\end{array}$ & $\begin{array}{l}\text { Terror,dr } \\
\text { ead,pain, } \\
\text { sorrow,jo } \\
\text { y,love,an } \\
\text { ger,dang } \\
\text { er }\end{array}$ \\
\hline Virtues & $\begin{array}{l}\text { Kind,trut } \\
\text { h,faith,wi } \\
\text { sdom,str } \\
\text { ength,car } \\
\text { e,knowle } \\
\text { dge }\end{array}$ & $\begin{array}{l}\text { Sacrifice, } \\
\text { wisdom, } \\
\text { art,grace, } \\
\text { kind,,rig } \\
\text { hteous,w } \\
\text { it }\end{array}$ & $\begin{array}{l}\text { Mercy,co } \\
\text { urage,wi } \\
\text { sdom,str } \\
\text { ength,tru } \\
\text { th,grace,f } \\
\text { aith,wit,c } \\
\text { are }\end{array}$ & $\begin{array}{l}\text { Truth,wi } \\
\text { sdom,str } \\
\text { ength,kin } \\
\text { d,care,tru } \\
\text { st }\end{array}$ & $\begin{array}{l}\text { Grace,wi } \\
\text { sdom,gra } \\
\text { ce,mercy } \\
\text {,kind,fait } \\
\text { h,courag } \\
\text { e }\end{array}$ & $\begin{array}{l}\text { Wisdom, } \\
\text { faith,sacr } \\
\text { ifice,stre } \\
\text { ngth }\end{array}$ & $\begin{array}{l}\text { Art,wisd } \\
\text { om,kind, } \\
\text { grace,car } \\
\text { e,wrath }\end{array}$ & $\begin{array}{l}\text { Mercy,ar } \\
\text { t,devotio } \\
\text { n,grace,f } \\
\text { aith,stren } \\
\text { gth,wisd } \\
\text { om,coura } \\
\text { ge }\end{array}$ & $\begin{array}{l}\text { Righteou } \\
\text { snes,sacr } \\
\text { ifice,trust } \\
\text {,wit,wisd } \\
\text { om,care, } \\
\text { wit }\end{array}$ & $\begin{array}{l}\text { Grace,wr } \\
\text { ath,courg } \\
\text { e,kind,ca } \\
\text { re,wisdo } \\
\text { m }\end{array}$ \\
\hline $\begin{array}{l}\text { Date/Tim } \\
\text { e }\end{array}$ & $\begin{array}{l}\text { Day,dark } \\
\text {,night,ho } \\
\text { ur,month } \\
\text {,dawn,ye } \\
\text { ar,today }\end{array}$ & $\begin{array}{l}\text { Dark,nig } \\
\text { ht,day,m } \\
\text { onth,daw } \\
\text { n,today,y } \\
\text { ear }\end{array}$ & $\begin{array}{l}\text { Day,nigh } \\
\text { t,mornin } \\
\text { g,dark,ho } \\
\text { ur,year,m } \\
\text { onth,spri } \\
\text { ng,today }\end{array}$ & $\begin{array}{l}\text { Night,da } \\
\text { y,dark,m } \\
\text { onth,hou } \\
\text { r,year,tod } \\
\text { ay }\end{array}$ & $\begin{array}{l}\text { Night,da } \\
\text { y,dark,ho } \\
\text { ur,morni } \\
\text { ng,dawn }\end{array}$ & $\begin{array}{l}\text { Day,nigh } \\
\text { t,hour,m } \\
\text { orning,da } \\
\text { rk,dawn, } \\
\text { month }\end{array}$ & $\begin{array}{l}\text { Dawn,da } \\
\text { y,mornin } \\
\text { g,night,d } \\
\text { ark,today }\end{array}$ & $\begin{array}{l}\text { Night,da } \\
\text { y,hour,to } \\
\text { day,morn } \\
\text { ing,dawn } \\
\text {,month }\end{array}$ & morning & $\begin{array}{l}\text { Month,m } \\
\text { orrow,to } \\
\text { day,day, } \\
\text { night }\end{array}$ \\
\hline $\begin{array}{l}\text { Earth/Pla } \\
\text { ce }\end{array}$ & $\begin{array}{l}\text { World,un } \\
\text { iverse,ea } \\
\text { rth,hell }\end{array}$ & $\begin{array}{l}\text { World,un } \\
\text { iverse,ea } \\
\text { rth,heave } \\
\text { n,hell, }\end{array}$ & $\begin{array}{l}\text { Earth,hea } \\
\text { ven,worl } \\
\text { d,Israel,p } \\
\text { aradise,h } \\
\text { ell,Babyl } \\
\text { on,Jerem } \\
\text { ia }\end{array}$ & $\begin{array}{l}\text { World,ea } \\
\text { rth,heave } \\
\text { n,hell }\end{array}$ & $\begin{array}{l}\text { World,un } \\
\text { iverse,ea } \\
\text { rth,heave } \\
\text { n,paradis } \\
\text { e }\end{array}$ & $\begin{array}{l}\text { Earth,hea } \\
\text { ven,hell, } \\
\text { world,un } \\
\text { iverse }\end{array}$ & $\begin{array}{l}\text { Heaven,e } \\
\text { arth,worl } \\
\text { d,univers } \\
\text { e }\end{array}$ & $\begin{array}{l}\text { World,ea } \\
\text { ryh,unive } \\
\text { rse,heave } \\
\text { n,hell }\end{array}$ & $\begin{array}{l}\text { Universe } \\
\text {,world,he } \\
\text { aven,eart } \\
\text { h }\end{array}$ & $\begin{array}{l}\text { Israel,eg } \\
\text { ypt,earth, } \\
\text { heaven,h } \\
\text { ell }\end{array}$ \\
\hline
\end{tabular}




\begin{tabular}{|c|c|c|c|c|c|c|c|c|c|c|}
\hline Plants & $\begin{array}{l}\text { Plant,frui } \\
\text { t,tree,flo } \\
\text { wer,root }\end{array}$ & $\begin{array}{l}\text { Wood,lot } \\
\text { us,tree,ro } \\
\text { ot,seed,pl } \\
\text { ant,herb,f } \\
\text { orest,gra } \\
\text { ss }\end{array}$ & $\begin{array}{l}\text { Tree,gras } \\
\text { s,forest,h } \\
\text { erb,plant, } \\
\text { branch,se } \\
\text { ed }\end{array}$ & $\begin{array}{l}\text { Forest,fl } \\
\text { ower,lotu } \\
\text { s,tree,gra } \\
\text { ss,sandal } \\
\text { wood,pla } \\
\text { nt,wood,r } \\
\text { oot,thorn } \\
\text {,seed }\end{array}$ & $\begin{array}{l}\text { Lotus,for } \\
\text { est,plant, } \\
\text { flower,sa } \\
\text { ndalwoo } \\
\text { d,wood,h } \\
\text { erb }\end{array}$ & $\begin{array}{l}\text { Tree,plan } \\
\text { t,seed,tho } \\
\text { rn,herb,fl } \\
\text { ower,roo } \\
\text { t }\end{array}$ & $\begin{array}{l}\text { Grass,pla } \\
\text { nt,wood,f } \\
\text { orest,tree } \\
\text {,herb,see } \\
\text { d,lotus }\end{array}$ & $\begin{array}{l}\text { Lotus,flo } \\
\text { wer,seed, } \\
\text { tree,plant } \\
\text {,wood,fo } \\
\text { rest,sand } \\
\text { alwood }\end{array}$ & $\begin{array}{l}\text { Plant,tree } \\
\text {,thorn,ro } \\
\text { ot }\end{array}$ & $\begin{array}{l}\text { Flower,g } \\
\text { rass,plant } \\
\text {,forest,ro } \\
\text { ot,tree }\end{array}$ \\
\hline God & $\begin{array}{l}\text { Lord,gur } \\
\text { u,God,G } \\
\text { oddess,S } \\
\text { ri,Mahav } \\
\text { ira }\end{array}$ & $\begin{array}{l}\text { Lord,Go } \\
\text { d,Vishnu } \\
\text {,Shiva,R } \\
\text { udra,Ya } \\
\text { ma,Indra, } \\
\text { Varuna,S } \\
\text { oma,Kali } \\
\text {,Krishna, } \\
\text { Arjuna,b } \\
\text { hagwan }\end{array}$ & $\begin{array}{l}\text { Lord,Go } \\
\text { d,Jesus,C } \\
\text { hrist,god } \\
\text { dess }\end{array}$ & $\begin{array}{l}\text { God,Lor } \\
\text { d }\end{array}$ & $\begin{array}{l}\text { Lord,Gur } \\
\text { u,Nanak, } \\
\text { God,Cre } \\
\text { ator }\end{array}$ & $\begin{array}{l}\text { Allah,Lo } \\
\text { rd,God }\end{array}$ & $\begin{array}{l}\text { Indra,go } \\
\text { d,soma,1 } \\
\text { ord,varu } \\
\text { na,indu,s } \\
\text { urya,rudr } \\
\text { a,brahasp } \\
\text { ati,godde } \\
\text { ss,visved } \\
\text { eva,saras } \\
\text { wati,yam } \\
\text { a,kali,vis } \\
\text { hnu }\end{array}$ & $\begin{array}{l}\text { Guru,Ra } \\
\text { dhasoami } \\
\text {,Lord,Go } \\
\text { d,Soami }\end{array}$ & Lord & $\begin{array}{l}\text { Lord,Go } \\
\text { d }\end{array}$ \\
\hline Eatables & milk & $\begin{array}{l}\text { Fruit,wat } \\
\text { er,food,b } \\
\text { utter,mil } \\
\text { k,salt,nec } \\
\text { tar }\end{array}$ & $\begin{array}{l}\text { Water,fr } \\
\text { uit,cake, } \\
\text { bread,sal } \\
\text { t,sweet,c } \\
\text { orn,whea } \\
\text { t,vine,mil } \\
\text { k,food,m } \\
\text { eat }\end{array}$ & $\begin{array}{l}\text { Water,fr } \\
\text { uit,milk, } \\
\text { honey }\end{array}$ & $\begin{array}{l}\text { Water,fr } \\
\text { uit,milk,s } \\
\text { weet,grai } \\
\text { n,butter,c } \\
\text { orn,hone } \\
\text { y,salt,bre } \\
\text { ad,cake, } \\
\text { wheat,gr } \\
\text { ape,meat }\end{array}$ & $\begin{array}{l}\text { Water,fo } \\
\text { od,grain, } \\
\text { vine,milk } \\
\text {,meat,ho } \\
\text { ney,grap } \\
\text { e,bread }\end{array}$ & $\begin{array}{l}\text { Water,jui } \\
\text { ce,milk,b } \\
\text { utter,grai } \\
\text { n,cake,co } \\
\text { rn,fruit,b } \\
\text { rley,hone } \\
\text { y,meat }\end{array}$ & $\begin{array}{l}\text { Water,mi } \\
\text { lk,butter, } \\
\text { fruit,grai } \\
\text { n,sweet,c } \\
\text { ake,salt }\end{array}$ & $\begin{array}{l}\text { Water,fo } \\
\text { od }\end{array}$ & $\begin{array}{l}\text { Milk,cak } \\
\text { e,honey, } \\
\text { vine,salt, } \\
\text { barley,w } \\
\text { heat,flou } \\
\text { r }\end{array}$ \\
\hline $\begin{array}{l}\text { Elements } \\
\text { of Nature }\end{array}$ & $\begin{array}{l}\text { Moon,su } \\
\text { n,air,ligh } \\
\text { t,rain,fire } \\
\text {,star,river } \\
\text {,sky,win } \\
\text { d,ocan,li } \\
\text { ght,sea }\end{array}$ & $\begin{array}{l}\text { Fire,light } \\
\text {,sun,ocea } \\
\text { n,moon, } \\
\text { wind,air, } \\
\text { river,rain } \\
\text {,lake,sky, } \\
\text { flame,sta } \\
\text { r }\end{array}$ & $\begin{array}{l}\text { Sky,ocea } \\
\text { n,air,win } \\
\text { d,sun,riv } \\
\text { er,light,s } \\
\text { ea,rain,m } \\
\text { oon }\end{array}$ & $\begin{array}{l}\text { Moon,wi } \\
\text { nd,fire,ai } \\
\text { r,rain,lig } \\
\text { ht,sun,sk } \\
\text { y,star,sea }\end{array}$ & $\begin{array}{l}\text { Light,oce } \\
\text { an,fire,su } \\
\text { n,rain,mo } \\
\text { on, wind,r } \\
\text { iver,air,s } \\
\text { ea }\end{array}$ & $\begin{array}{l}\text { Fire,sky,1 } \\
\text { ight,river } \\
\text {,moon,wi } \\
\text { nd,sea,oc } \\
\text { ean, }\end{array}$ & $\begin{array}{l}\text { Sun,moo } \\
\text { n,light,sk } \\
\text { y,river,ra } \\
\text { in,air,win } \\
\text { d,fire,star }\end{array}$ & $\begin{array}{l}\text { Sun,mon, } \\
\text { ocean,sk } \\
\text { y,light,fl } \\
\text { ame,rain, } \\
\text { fire,star,r } \\
\text { iver,sea }\end{array}$ & $\begin{array}{l}\text { River,oc } \\
\text { ean,sky,li } \\
\text { ght,air,wi } \\
\text { nd }\end{array}$ & $\begin{array}{l}\text { Sun,rain, } \\
\text { moon,sta } \\
\text { r,flame,s } \\
\text { ky,sea,ri } \\
\text { ver,ocea } \\
\text { n }\end{array}$ \\
\hline Events & $\begin{array}{l}\text { Birth,hol } \\
\text { i,wear,he } \\
\text { aven,mar } \\
\text { iage }\end{array}$ & $\begin{array}{l}\text { Death,ba } \\
\text { ttle,war }\end{array}$ & $\begin{array}{l}\text { Death,ba } \\
\text { ttle,marri } \\
\text { age,birth }\end{array}$ & $\begin{array}{l}\text { Death,bir } \\
\text { th }\end{array}$ & $\begin{array}{l}\text { Death,ho } \\
\text { li,birth,B } \\
\text { asant,batt } \\
\text { le }\end{array}$ & birth & $\begin{array}{l}\text { Holi,battl } \\
\text { e,birth,m } \\
\text { arriage }\end{array}$ & $\begin{array}{l}\text { Holi,deat } \\
\text { h, birth,B } \\
\text { asant, war }\end{array}$ & $\begin{array}{l}\text { Death,ba } \\
\text { ttle,war }\end{array}$ & $\begin{array}{l}\text {,marriage } \\
\text {,birth }\end{array}$ \\
\hline $\begin{array}{l}\text { Precious } \\
\text { Stone/ } \\
\text { Metal }\end{array}$ & gold & $\begin{array}{l}\text { Gold,iro } \\
\text { n,pearl,or } \\
\text { nament }\end{array}$ & $\begin{array}{l}\text { Gold,silv } \\
\text { er,iron,br } \\
\text { ass,pearl, } \\
\text { diamond, } \\
\text { ornament } \\
\text { s }\end{array}$ & $\begin{array}{l}\text { Gold,silv } \\
\text { er,iron,di } \\
\text { amond,je } \\
\text { wel }\end{array}$ & $\begin{array}{l}\text { Gold,silv } \\
\text { er,iron,br } \\
\text { ass,diam } \\
\text { ond,jewe } \\
\text { 1,orname } \\
\text { nt }\end{array}$ & $\begin{array}{l}\text { Gold,silv } \\
\text { er,brass,p } \\
\text { earl,orna } \\
\text { ment }\end{array}$ & $\begin{array}{l}\text { Gold,iro } \\
\text { n,brass,p } \\
\text { earl,jewe } \\
\text { 1,orname } \\
\text { nt }\end{array}$ & $\begin{array}{l}\text { Gold,silv } \\
\text { er,iron,di } \\
\text { amond,p } \\
\text { earl,jewe } \\
\text { l,orname } \\
\text { nt }\end{array}$ & - & $\begin{array}{l}\text { Gold,jew } \\
\text { el,brass,o } \\
\text { rnament }\end{array}$ \\
\hline Animals & $\begin{array}{l}\text { Elephant, } \\
\text { cow,hors } \\
\text { e,bear,de } \\
\text { er,snake, } \\
\text { fish,bird, } \\
\text { cattle,lio } \\
\text { n }\end{array}$ & $\begin{array}{l}\text { Cow,hor } \\
\text { se,elepha } \\
\text { nt,serpen } \\
\text { t,fish,dog } \\
\text {,bee,calf, } \\
\text { bird,lion, } \\
\text { cattle }\end{array}$ & $\begin{array}{l}\text { Lamb,ho } \\
\text { rse,cattle, } \\
\text { bird,lion, } \\
\text { bear,drag } \\
\text { on,calf,h } \\
\text { erd,sheep } \\
\text {,dog,serp } \\
\text { ent,worm } \\
\text {,camel,b } \\
\text { ull,hawk }\end{array}$ & $\begin{array}{l}\text { Elephant } \\
\text { s,horse,bi } \\
\text { rd,swan,f } \\
\text { ish,cow,b } \\
\text { ee,calf }\end{array}$ & $\begin{array}{l}\text { Herd,bea } \\
\text { r,bull,fis } \\
\text { h,elepha } \\
\text { nt,bird,se } \\
\text { rpent,hor } \\
\text { se,dear,s } \\
\text { wan,lion, } \\
\text { cow,wor } \\
\text { m,dog,ha } \\
\text { wk,calf,s } \\
\text { heep,bee, } \\
\text { camel,dr } \\
\text { agon }\end{array}$ & $\begin{array}{l}\text { Bird,bee, } \\
\text { goat,bear } \\
\text {,fish,dog, } \\
\text { calf,cattl } \\
\text { e,horse,el } \\
\text { ephant,c } \\
\text { ow,serpe } \\
\text { nt,herd }\end{array}$ & $\begin{array}{l}\text { Horse,co } \\
\text { w,bull,ca } \\
\text { ttle,bird, } \\
\text { bear,drag } \\
\text { on,deer,h } \\
\text { erd,calf,s } \\
\text { wan,serp } \\
\text { ent,dog,e } \\
\text { lephant,li } \\
\text { on,bee,sh } \\
\text { eep,fish, } \\
\text { oxen }\end{array}$ & $\begin{array}{l}\text { Bird,fish, } \\
\text { snake,ser } \\
\text { pent,swa } \\
\text { n,bee,ele } \\
\text { phant,do } \\
\text { g,lion,de } \\
\text { er,bear,c } \\
\text { ow,calf }\end{array}$ & $\begin{array}{l}\text { Horse,do } \\
\text { g,fish,bir } \\
\text { d }\end{array}$ & $\begin{array}{l}\text { Herd,bir } \\
\text { d,sheep,s } \\
\text { erpent,ca } \\
\text { mel,wor } \\
\text { m,dog,ha } \\
\text { wk,lion,s } \\
\text { nake,bee, } \\
\text { cow,bull, } \\
\text { shekel,la } \\
\text { mb,goat }\end{array}$ \\
\hline
\end{tabular}

